\title{
EFEKTIVITAS MOBILISASI DINI DALAM PEMULIHAN LUKA PASIEN POST OPERASI SECTIO CAESAREA DI RUANG FLAMBOYAN RUMAH SAKIT IBU KARTINI KISARAN
}

\section{Effectiveness of Early Mobilization in the Recovery of Post Operating Sectio Caesarea Patients in Flamboyan Room Mother's Hospital Kartini Kisaran}

\author{
Sri Legawati ${ }^{1}$, Nurnelam Nasution ${ }^{1}$ \\ ${ }^{1}$ Akademi Keperawatan Gita Matura Abadi Kisaran, Jalan Marah Rusli No 45 Kisaran \\ Kabupaten Asahan Sumatera Utara \\ Email: srilegawati2@gmail.com, akperyagma@gmail.com
}

\begin{abstract}
Abstrak
Sectio caesarea adalah pembedahan untuk melahirkan janin dengan membuka dinding perut dan dinding uterus. Terkait itu, perlu di ingat bahwa seorang ibu yang telah mengalami pembedahan itu merupakan seorang yang memerlukan pengawasan yang cermat berhubung dengan bahaya ruptura uteri. Tujuan Penelitian ini untuk mengetahui gambaran efektifitas mobilisasi dini dalam membantu pemulihan luka pasien post operasi sectio caesarea di Ruang Flamboyan Rumah Sakit Ibu Kartini Kisaran.

Desain penelitian bersifat deskriftif dengan menggunakan penelitian observasional dengan cara accidental. Populasi dalam penelitian ini adalah pasien yang datang pada saat dilakukan observasi post Sectio Caesarea di Rumah Sakit Ibu Kartini Kisaran. Sampel yang di gunakan yaitu accidental sampling, sehingga di dapat responden sebanyak $20 \mathrm{ibu}$ Berdasarkan hasil penelitian dari efektifitas mobilisasi dini dalam Pemulihan Lukada Pasien Post Operasi Sectio Caesarea diperoleh hasil 13,55 (90,33 \%). Maka dapat di simpulkan bahwa ibu baik dalam melakukan mobilisasi dini. Kesimpulannya ibu memiliki kategori yang baik dalam melakukan mobilisasi dini dalm pemulihan luka operasi.
\end{abstract}

Kata kunci: efektifitas, mobilisasi dini, sectio caesarea

\begin{abstract}
Sectio caesarea is surgical operation for giving birth an embryo by opening abdominal wall and uterus wall. However, we need to remember that another having surgery is someone need a carefull supervision relating with the dangerous ruptura uteri. The purpose of this research is to identify early mobilization effective illustration to help the discovering of patients' injured after sectio caesarea surgery in flamboyan room Ibu Kartini hospital Kisaran

The research design is descriptive by using observasional research by using accidental. The populations in this research are patients coming while doing post sectio caesarea observation in ibu kartini hospital kisaran. By using accidental sample in order to get respondents for 20 mothers.

Based on the result of the research from early mobilization effective in discovering on the injured of caesarea sectio operation post patient get the result 13,55 (90,33\%). So the conclusion is a good mother in doing eraly mobilization. The conclusion is a mother has a good category in doing early mobilization in discovering the operation injured.
\end{abstract}

Keywords: effectiveness, early mobilization, sectio caesarea

\section{PENDAHULUAN}

Menurut Prawirohardjo (2005), sectio caesarea adalah pembedahan untuk melahirkan janin dengan membuka dinding perut dan dinding uterus.

Sectio caesarea ini jauh lebih aman daripada dahulu berhubung dengan adanya antibiotika, transfusi darah, teknik operasi yang lebih sempurna dan anastesia yang lebih baik. Karena itu kini ada kecenderungan untuk melakukan sectio caesarea tanpa dasar yang cukup kuat.

Dalam hubungan ini perlu diingat bahwa seorang ibu yang telah mengalami pembedahan itu merupakan seorang yang mempunyai parut dalam uterus, dan setiap kehamilan serta persalinan berikutnya memerlukan pengawasan yang cermat berhubung dengan bahaya ruptura uteri, walaupun bahaya ini dilakukan dengan teknik yang sempurna. 
Menurut World Health Organization (WHO), standar rata-rata sectio caesarea di sebuah negara adalah sekitar 5-15\% per 1000 kelahiran di dunia, rumah sakit pemerintah rata-rata $11 \%$, sementara di rumah sakit swasta bisa lebih dari $30 \%$. Permintaan sectio caesarea (SC) di sejumlah negara berkembang melonjak pesat setiap tahun nya. Secara umum jumlah persalinan sectio caesarea (SC) di Indonesia sekitar 30$80 \%$ dari total persalinan. Beberapa kerugian dari persalinan yang dijalani melalui sectio caesarea yaitu adanya komplikasi lain yang dapat terjadi saat tindakan dengan frekuensi di atas $11 \%$ (Kemenkes RI, 2013).

Menurut Bobak (2005), empat kategori diagnostik merupakan alasan terhadap 75\% sampai $90 \%$ sectio caesarea, yakni: distosia, sesaria tulang, persentasi bokong, dan gawat janin.

Indikasi lain prosedur tersebut mencakup infeksi virus herpes, prolaps tali pusat (prolapsed umbilical cord), komplikasi medis, seperti hipertensi akibat kehamilan (pregnancy-induced hypertention), kelainan plasenta, seperti plasenta previa dan solusio plasenta, malpresentasi, misalnya, presentasi bahu dan anomali janin, misalnya hidrosefalus.

Menurut Alimul (2008), mobilitas atau mobilisasi merupakan kemampuan individu untuk bergerak secara bebas, mudah, dan teratur dengan tujuan untuk memenuhi kebutuhan aktivitas guna mempertahankan kesehatan nya.

Menurut Damai dan Dian (2015), ambulasi dini (early ambulation) adalah mobilisasi segera setelah ibu melahirkan dengan membimbing ibu untuk bangun dari tempat tidurnya. Ibu post partum diperbolehkan bangun dari tempat tidurnya 24-48 jam setelah melahirkan. Anjurkan ibu untuk memulai mobilisasi dengan miring kanan/kiri, duduk kemudian berjalan.

Menurut penelitian, mobilisasi dini tidak berpengaruh buruk, tidak menyebabkan perdarahan abnormal, tidak memengaruhi penyembuhan luka episiotomi maupun luka diperut, serta tidak memperbesar kemungkinan prolapsus uteri.

Berdasarkan survei awal yang telah di lakukan peneliti di Rumah Sakit Umum Ibu Kartini Kisaran, ibu melahirkan sectio caesarea sebanyak 15 orang dengan anjuran mobilisasi setelah 24 jam post operasi sectio caesarea didapat penyembuhan SC lebih cepat/efektif dengan menggunakan teknik ambulasi miring kanan dan kiri dan pada hari kedua mulai berdiri dan berjalan diarea sekitar tempat tidur.

\section{METODE PENELITIAN}

Penelitian ini adalah jenis penelitian yang bersifat deskriptif dengan menggunakan penelitian observasional dengan cara accidental. Pada penelitian ini penulis hanya melakukan observasi (pengamatan). Alasan penulis menggunakan metode ini karena tujuan dari penelitian ini adalah untuk mengetahui gambaran efektivitas mobilisasi dini pada ibu post operasi seksio caesarea dengan proses penyembuhan luka operasi di ruang Flamboyan Rumah Sakit Umum Ibu Kartini Kisaran tahun 2017.

Penelitian dilakukan di Rumah Sakit Umum Ibu Kartini Kisaran. Waktu penelitian direncanakan mulai bulan Februari sampai Agustus 2017. Populasi penelitian ini adalah pasien yang datang pada saat dilakukan observasi post $S C$ di RSU Ibu Kartini Kisaran.

Pengambilan sampel dilakukan dengan cara accidental sampling pada pasien post operasi seksio sesarea yang dirawat di ruang rawat Flamboyan Rumah Sakit Umum Ibu Kartini Kisaran dengan kriteria pengambilan sampling yaitu pasien post $S C$ primigravida maupun multigravida, wanita usia 20 sampai dengan 40 tahun, bersedia menjadi responden tanpa melihat tingkat pendidikan dan agama. Sesuai dengan kriteria, maka penulis mengambil sampel sebanyak 20 orang.

Data yang dikumpulkan oleh peneliti langsung dari sumber data atau responden secara observasi, dan wawancara.

Untuk mengetahui gambaran efektivitas mobilisasi dini dalam pemulihan luka pada pasien post operasi sectio caesarea, peneliti menyiapkan pertanyaan dari mobilisasi dini sebanyak 15 pertanyaan dalam bentuk kuisioner. Pengukuran ini dengan menggunakan skala penilaian skala Guttman. Skala ini merupakan skala yang bersifat tegas seperti jawaban dari pertanyaan/pernyataan: setuju dan tidak setuju. Skala Guttman ini pada umumnya dibuat dari checklist dengan interprestasi 
penilaian, skor yang mengatakan Ya nilai nya 1 dan apabila tidak nilainya 0 . (Alimul, 2007).

\section{Uji Validitas}

Syarat untuk uji validitas dalam Spss adalah: jika nilainya $>0,300$ maka dinyatakan valid, maka jika<dari 0,300 dinyatakan tidak valid.

\section{Uji Reliabilitas}

Reliabilitas adalah indeks yang menunjukkan sejauh mana suatu alat pengukur dapat di percaya atau dapat di andalkan. (Notoatmodjo, 2014).

Syarat untuk data uji reliabilitas adalah bila nilai data dalam penghitungan rumus Spss>0,600 maka dinyatakan baik sedangkan jika sebaliknya yaitu $<0.600$ dinyatakan buruk.

Tabel 1. Uji Reliabilitas Kuisioner

\begin{tabular}{ccc}
\hline No. & Uji Reliabilitas & Keterangan \\
\hline 1. & 0,763 & Baik \\
\hline
\end{tabular}

Berdasarkan uji reabilitas data, maka data kuisoner yang digunakan untuk setiap pertanyaan dapat digunakan karena nilai nya lebih dari 0,600 dan kategori baik.

\section{HASIL DAN PEMBAHASAN}

Tabel 2. Aspek Pengukuran Gambaran Efektifitas Mobilisasi Dini dalam Pemulihan Luka Post Operasi Sectio Caesarea

\begin{tabular}{ccccl}
\hline No & $\begin{array}{c}\text { Jum- } \\
\text { lah }\end{array}$ & $\begin{array}{c}\text { Res- } \\
\text { ponden }\end{array}$ & Hasil & $\begin{array}{c}\text { Kete- } \\
\text { rangan }\end{array}$ \\
\hline 1. & 18 & 20 & 0,9 & \\
2. & 19 & 20 & 0,95 & \\
3. & 16 & 20 & 0,8 & Rumus: \\
4. & 20 & 20 & 1 & Hasil $=$ \\
5. & 19 & 20 & 0,95 & Total \\
6. & 19 & 20 & 0,95 & $\underline{\text { Skor }}$ \\
7. & 16 & 20 & 0,8 & Responde \\
8. & 19 & 20 & 0,95 & n \\
9. & 19 & 20 & 0,95 & Total \\
10. & 18 & 20 & 0,9 & hasil \\
11. & 18 & 20 & 0,9 & X 100\% \\
12. & 16 & 20 & 0,8 & Bobot \\
13. & 17 & 20 & 0,85 & Maximal \\
14. & 19 & 20 & 0,95 & Maka : \\
15. & 18 & 20 & 0,9 & $\underline{13,55} \mathrm{x}$ \\
& & & & $100 \%=$ \\
& & & & $90,33 \%$ \\
& \multirow{2}{*}{$\Sigma$} & & 13,55 & 15 \\
& & & & (Kategori \\
& & & & Baik) \\
\hline
\end{tabular}

Berdasarkan dari aspek pengukuran didapat kategori efektifitas mobilisasi dini dengan skor 13,55 (90,33\%) dengan judul Efektivitas Mobilisasi Dini dalam Pemulihan Luka pada Pasien Post Operasi Sectio Caesarea di Rumah Sakit Ibu Kartini Kisaran dikategorikan "Baik", terbukti bahwa $90 \%$ responden menyatakan sudah melakukan gerakan dini seperti menggerak kan jari-jari tangan dan kaki setelah delapan jam pertama operasi Sectio Caesarea yang bertujuan untuk pemulihan luka post operasi.

Selanjutnya $95 \%$ responden menyatakan sudah miring kanan/kiri setelah delapan jam pertama operasi untuk mempercepat pemulihan pada luka operasi Sectio Caesarea.

Dari data di tabel 2, menyatakan bahwa $80 \%$ responden menyatakan yang melakukan tirah baring lebih dari 8 jam setelah operasi Sectio Caesarea beresiko terjadinya Trombosis (pembekuan darah) dalam sirkulasi.

Selanjutnya, $100 \%$ Responden menyatakan sudah melakukan tekhnik nafas dalam dan batuk efektif guna melonggarkan pernafasan dan sekaligus menumbuhkan kepercayaan diri ibu untuk pulih.

Dari tabel ditemukan bahwa 95\% Responden menyatakan sudah menekuk dan meluruskan tungkai secara bergantian setelah 8 jam operasi SC guna untuk membantu sirkulasi darah. 95\% Responden menyatakan sudah melakukan gerakan memutar kepala ke kiri ke kanan untuk merileks kan otot-otot leher. $80 \%$ Responden menyatakan sudah berbaring di tempat tidur dengan posisi setengah duduk pada 12 jam pertama setelah operasi Sectio Caesarea guna mempercepat pemulihan ibu. 8. $95 \%$ Responden menyatakan sudah turun dan berdiri dari tempat tidur setelah 48 jam operasi SC dapat membantu ibu segera mungkin melakukan aktivitas yang lain.

Selanjutnya dalam tabel tersebut dimukan hasil bahwa 95\% Responden menyatakan sudah berjalan, berkeliling dan tidak hanya duduk dikursi setelah 48 jam operasi SC agar memulihkan segera kekuatan ibu. 90\% Responden menyatakan sudah melakukan pergerakan dini setelah operasi tanpa mengkhawatirkan luka jahitan akan terbuka. 80\% Responden menyatakan mampu sudah berjalan,berkeliling dan tidak 
hanya duduk dikursi setelah 48 jam operasi SC agar memulihkan segera kekuatan ibu. 80\% Responden menyatakan mampu menahan BAK dapat menghambat penyembuhan karena adanya penekanan pada jahitan luka.

Dalam pembahasan selanjutnya, 95\% Responden menyatakan mampu sudah melakukan Inisiasi Menyusu Dini guna membantu mempercepat proses penyembuhan luka Sectio Caesarea.95\% Responden menyatakan mampu melakukan gerakan dini setelah operasi SC dapat melancarkan pengeluaran darah selama masa nifas. 90\% Responden menyatakan tidak melakukan gerakan dini setelah operasi SC bersesiko terkena infeksi post operasi Sectio Caesar.

\section{KESIMPULAN}

Berdasarkan dari aspek pengukuran di dapat kategori efektifitas mobilisasi dini dengan score 13,55 (90,33 \%) dengan judul efektifitas Mobilisasi Dini dalam Pemulihan Luka pada Pasien Post Operasi Sectio Caesarea di Rumah Sakit Ibu Kartini Kisaran dikategorikan baik, terbukti bahwa kategori efektivitas dalam aspek mobilisasi dini pemulihan luka pasien post operasi sectio caesarea yaitu tindakan sudah melakukan gerakan dini seperti menggerakkan jari-jari tangan dan kaki setelah delapan jam pertama operasi Sectio Caesarea yang bertujuan untuk pemulihan luka post operasi, sudah miring kanan/kiri setelah delapan jam pertama operasi untuk mempercepat pemulihan pada luka operasi Sectio Caesarea, melakukan tirah baring lebih dari 8 jam setelah operasi Sectio Caesarea beresiko terjadinya trombosis (pembekuan darah) dalam sirkulasi.

Sudah melakukan teknik nafas dalam dan batuk efektif guna melonggarkan pernafasan dan sekaligus menumbuhkan kepercayaan diri ibu untuk pulih, sudah menekuk dan meluruskan tungkai secara bergantian setelah delapan jam pertama operasi Sectio Caesarea guna untuk membantu sirkulasi darah, sudah melakukan gerakan memutar kepala ke kiri ke kanan untuk merileks kan otot-otot leher, sudah berbaring di tempat tidur dengan posisi setengah duduk pada 12 jam pertama setelah operasi Sectio Caesarea guna mempercepat pemulihan ibu, sudah bangun dari tempat tidur setelah 24-48 jam operasi agar diharapkan sel mendapatkan suplai oksigen melalui pergerakan yang dilakukan, sudah turun dan berdiri dari tempat tidur setelah 48 jam operasi Sectio Caesarea dapat membantu ibu segera mungkin melakukan aktivitas yang lain, sudah berjalan, berkeliling, dan tidak hanya duduk di kursi setelah 48 jam operasi Sectio Caesarea agar memulihkan segera kekuatan ibu, sudah melakukan pergerakan dini setelah operasi tanpa mengkhawatirkan luka jahitan akan terbuka, sering menahan BAK dapat menghambat penyembuhan karena adanya penekanan pada jahitan luka, udah melakukan Inisiasi Menyusu Dini guna membantu mempercepat proses penyembuhan luka operasi, sudah melakukan gerakan dini setelah operasi Sectio Caesarea dapat melancarkan penegeluaran darahselam masa nifas, dan tidak melakukan gerakan dini setelah operasi Sectio Caesarea beresiko terkena infeksi post operasi.

\section{SARAN}

Bagi Ibu, diharapkan kepada ibu untuk selalu melakukan pergerakan dini dan menerapkan penting nya efektifitas mobilisasi dini dalam pemulihan luka post operasi Sectio Caesarea.

Bagi tenaga kesehatan, diharapkan perlu upaya untuk lebih meningkatkan pencapaian pergerakan dini yaitu:

1. Perlu penyebaran informasi tentang mobilisasi dini dengan memasang poster menyediakan buku-buku yang mendukung program mobilisasi dini keseluruh tempat pelayanan kesehatan.

2. Memberikan bimbingan dan penyuluhan tentang pergerakan dini yang benar oleh petugas kesehatan.

3. Sebagai petugas kesehatan harus memberikan penjelasan betapa pentingnya Mobilisasi dini bagi ibu serta menjelaskan akibat dari kemungkinan yang terjadi bila kurang pergerakan dini.

\section{DAFTAR PUSTAKA}

Bobak dkk, 2008. Ketrampilan Dasar Praktik Klinik untuk Kebidanan, Jakarta, Salemba Medika.

Chandranita, 2009. Memahami Kesehatan Reproduksi Wanita, Jakarta, EGC 
Gurning, F.P. 2017. Pembinaan Puskesmas Terhadap Pelaksanaan Program Usaha Kesehatan Sekolah Di Wilayah Kerja Puskesmas Padang Matinggi Kota Padangsidimpuan. Jurnal Ilmiah Penelitian Kesehatan (Jumantik). http://jurnal.uinsu.ac.id/index.php/kes mas/arti cle/view/1190 Tanggal Akses 2 Agustus 2017.

Gurning, F.P. 2017. Pengaruh Karakteristik Kader Terhadap Keaktifan Kader Posyandu Di Desa Bahung SibatuBatu Kecamatan Sei Dadap Kabupaten Asahan. Jurnal Ilmiah Penelitian Kesehatan (Jumantik). http://jurnal.uinsu.ac.id/index.php/kes mas/arti cle/view/1191 Tanggal Akses 2 Agustus 2017

Hidayat, Alimul Aziz A, 2007. Metode Penelitian Keperawatan dan Teknik Analisa Data, Jakarta, Salemba Medika.

Kamus Besar Bahasa Indonesia, 1983. Jakarta, Balai Pustaka

Lisnawati, L. 2013. Asuhan Kebidanan Terkini Kegawatdaruratan Maternal dan Neonatal, Cetakan Pertama, Jakarta, CV. Trans Info Media

Maryunani dan Sukaryati, 2011, Senam Hamil Senam Nifas dan Terapi Musik, Jakarta, CV. Trans Info Media

Notoatmodjo, S. 2014. Metodologi Penelitian Kesehatan, Jakarta, Rineka Cipta.
Nursalam, 2008, Konsep dan Penerapan Metodologi Penelitian Ilmu. Keperawatan, Jakarta, Salemba Medika

Pratama, M. Y. 2012. Pengaruh Quality of Work Life Terhadap Kinerja Perawat Pelaksana di Rumah Sakit Tk II Putri Hijau Kesdam I/BB Medan. Universitas Sumatera Utara. Medan.

Pratama, M.Y. 2017. Analisis Kualitas Kehidupan Kerja Perawat Pelaksana di Rumah Sakit Putri Hijau Medan. Jurnal Ilmiah Penelitian Kesehatan (Jumantik).

http://www.jurnal.uinsu.ac.id/index.p $\mathrm{hp} /$ kesm as/article/view/1192, tanggal akses 1 Agustus 2017.

Prawirohardjo, S. 2005. Ilmu Kebidanan, Jakarta, Bina Pustaka

Uliyah, Hidayat, 2008. Ketrampilan Dasar Praktik Klinik untuk Kebidanan, Salemba, Jakarta.

Yanti dan Sundawati, 2015, Asuhan Kebidanan Masa Nifas, Bandung, Refika Aditama. http:www.ejournal. kasussectiocaesarea.blog.ac.id diakses pada tanggal 24 Februari 2017. 